\title{
A study on exchange rate risk through lagged predictors, market risk and financial sector indi- cators: Time series analysis from Kuwait
}

\author{
Ahmed Nahar Al Hussaini ${ }^{a^{*}}$
}

${ }^{a}$ The Public Authority for Applied Education \& Training, The College of Business Studies, State of Kuwait

CH R O I CLE A B S T RACT

Article history:

Received: October 2, 2018

Received in revised format: No-

vember 15, 2018

Accepted: November 18, 2018

Available online:

November 18, 2018

Keywords:

Exchange rate

Interest rate

Lagged ER

Financial sector

Kuwait

\begin{abstract}
This paper investigates the impact of lagged-exchange rate along with market risk and financial sector indicators on country risk in Kuwait. For this purpose, time series analyses both in aggregated and disaggregated approach are conducted along with the correlation and descriptive outcomes. Overall study sample is divided into fourth groups; namely the whole-time period, 1980 to 1990,1991 to $2000,1991-2005$ and finally $1995-2005$. To achieve this objective, regression equations are developed, indicating the set of lagged predictors along with market and financial sector indicators of exchange rate volatility. For the whole sample of the study, it is found that exchange rate lagged values are significant predictors of country risk from 1980 to 2005 . Under the first subsample, lagged 1 and market risk through real interest rate are blamed for creating exchange rate (ER) volatility. For the $2^{\text {nd }}$ disaggregated analysis, the factors like lagged 1 of ER along with deposit interest (DIR) and price level of the Government (PLG) are significant predictors of exchange rate. Additionally, during the period 1995-2005, none of the regression models appears to create the exchange rate volatility. However, for the last disaggregated time series analysis, it is found that ERL1, and PLG significantly determine the country risk in the region of Kuwait. Findings of the study are contributing in the present literature while confirm the fact that lagged values of exchange rate are very much significant to be observed to understand the current trend in ER. Besides, the results can also support the argument that exchange rate risk and interest rate are interlinked with each other.
\end{abstract}

\section{Introduction}

The factor of risk in overall financial sector and economy is assumed to be among the most significant factors. In recent years, two major issues in the field of finance are the shift and volatility in the exchange rate and the level of financial sector indicators along the market risk (Obstfeld \& Rogoff, 1995; Sercu \& Vanhulle, 1992; Wekke, 2015). In the field of corporate finance and international financial management, one of the significant decisions taken by the financial managers and country experts is know how to secure the business firm from the situation of country risk and uneven financial shocks (Eiteman et al., 2007; Madura \& McCarty, 1989; Madura \& Zhang, 2006; Su, 2018). This problem is present in both developed and developing economies, however less developed countries (LDCs) must

* Corresponding author.

E-mail address: drahmednahar@gmail.com (A. N. Al Hussaini) 
focus more on better efficiency of the stock market or how to regularize the existing ones (Hall, 2018). In the recent time, a study in the field of finance conducted by Yiadom (2016) focused on the exchange rate movements (ESMs) with the adoption of floating exchange rates at independent context. The significant contribution is to investigate the causal interaction of exchange rate as a country risk factor and overall stock market. The problem of country risk in the form of exchange rate exists in almost those states having economic and financial issues and lack of proper planning and financial liberalization. The uncertainty in the value of exchange rate can hamper the financial health of the country with the result of higher risk (Fattouh, 2007; Suardi Wekke et al. 2017).

For the business firms, the exposure of exchange rate risk cannot be ignored specifically for those dealing with the financial services like banks. Various models are presented in existing literature covering the measurement for the exchange rate risk. Various studies have also examined the exchange rate as country risk affecting the firm performance along with other indicators (Sercu \& Uppal, 2006; Lubis \& Wekke, 2009). Contemporary year's globalization along with the integration of the financial markets and regional economies have suggested that risk factors like exchange rate are significantly affecting the regional and business output (Aftab \& Rehman, 2017). As it is a key issue, various emerged and emerging economies have focused on the stability of their exchange rate to hamper the exchange rate fluctuations and its influence on country risk. For instance, in China for many decades, government has used the fixed rate regime after the collapse of exchange rate system under the title of Bretton Woods agreement. Such decision has provided China with enough strength to maintain the level of competition in the world's economy. In addition, in the European Union, a common currency has been introduced common currency under the title of Euro for the sake of curbing the effect of fluctuation in the exchange rate in its member states. This decision has helped the EU for the bilateral trade as well. The role of the central bank in the regional economies is to maintain currency stability to secure the country from uneven financial shocks and trade deficits (Aftab \& Rehman, 2017).

In the region of Gulf, Dinar was introduced during the time of 1961 with the initial exchange rate of equal to one British pound. With the invasion of Iraq in Kuwait during the time of 1990, the currency of Iraqi dinar replaced the Kuwait dinar with the significant quantity. However, after the liberalization, the currency of dinar is restored in the region of Kuwait as a national note. During the issuance to now, five series of currency notes have been printed with the fifth version issued in 1994. During the time of March 18, 1975, to the year 2003, the dinar was pegged to the weighted currency basket from January 2003 to the mid-2007. During this time, pegging was switched to the exchange rate of 1 US\$ which is equal to 0.299 dinar with the overall margin of $+/-3.5$ percent. In the meantime, the central rate was translated to 1 dinar which was equal to 3.337 dollars. However, during the time of June 2007, the currency of Kuwait was repegged to the basket of currencies and in present years, it worth 3.609 US dollars, hence making it the highest valued currency unit in the world economy. Fig. 1 explains the overall trend of Kuwaiti dinar over last one year.

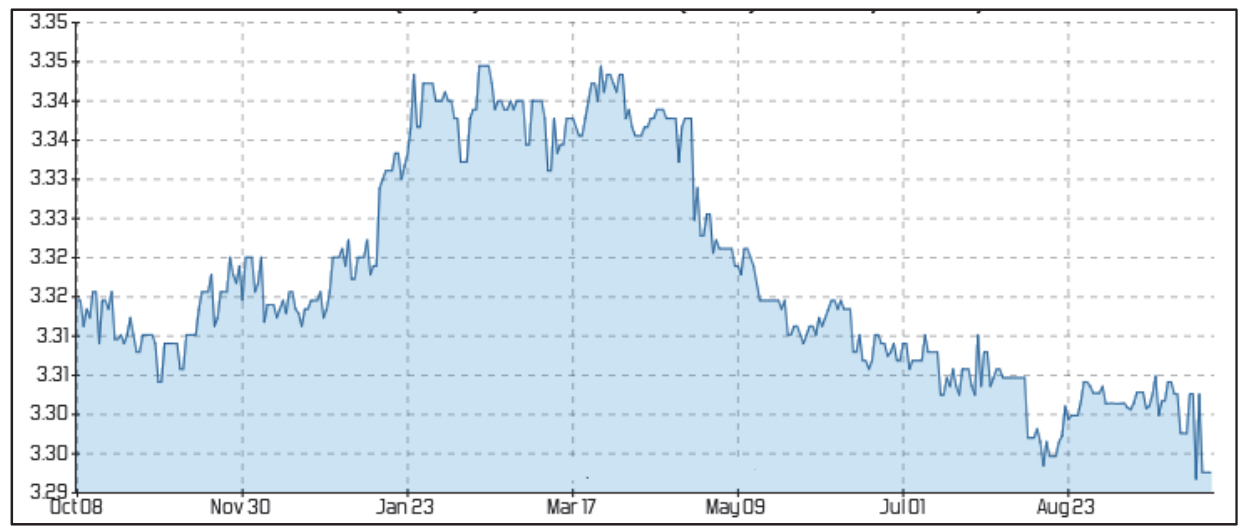

Fig. 1. Exchange rate Movements KWD to USD

Source: Fx-exchnage (2018) 
The rest of the paper is structured into the following sections. Section 2 indicates the main literature contribution from the context of the exchange rate, market risk and financial sector indicators. Section 3 deals with the variables and their descriptions along with the hypothetical association between them. Section 4 covers the econometric models of the study and their descriptions. Section 5 explains the data trends and empirical findings. Section 6 covers the conclusion and future implications of the study.

\section{Literature context of the study}

Numerous studies are conducted to uncover the idea of exchange rate exposures through key indicators from both emerging and developed economies. The study of Hooper and Kohlhagen (1978) provided the initial contribution among other researchers which covers the idea of exchange rate volatility with respect to its effect on trade and other indicators. Doğanlar (2002) contributed to the literature work while taking five emerging economies including the Malaysian region through Engle-Granger technique from 1980-Q1 to 1996-Q4. Arize et al. (2000) investigated the effect of real exchange-rate volatility on the export flows of 13 LDC's over the quarterly period 1973-1996. They reported that increases in the volatility of the real effective exchange rate, approximating exchange-rate uncertainty, yield a negative impact on export demand in both the short-run and the long-run.

Authors like Doroodian (1999) examines the exchange rate volatility in three countries like Korea, India and Malaysia from 1973 to 1996, through GAARCH model, it is found that exchange rate movements are significant for the overall financial and economic health of the countries. Sauer and Bohara (2001) narrate the volatility in the ER through panel regression models in both advanced and developed economies. During the last decade, some other studies have investigated ER through aggregated analysis. For instance, Wong and Tang (2008) examine electrical industries in selected regions for the ER movement through the ARDL approach. For the time of 1990 to 2001, it is suggested that volatility in ER acts significantly for the selected regions. Wong and Tang (2011) conducted their empirical work on semiconductor industry and provided some evidence about the risk-averse traders in the industry. Bahmani-Oskooee and Harvey (2006) explained their findings through ARDL approach and stated that depreciation in the exchange rate and bilateral out-payments are important factors for the financial health of the country.

In earlier years, some researchers investigated whether or not productivity of the different states could significantly increase through the real exchange rate and its movement (Balassa, 1964; Ghura \& Grennes, 1993). In addition, Miyakoshi (2003) performed an investigation on real exchange rate and found that it is more significant in the region of Indonesia and Philippines as compared with Korea, and Malaysia.

In contrast, the study of Miyakoshi (2003) investigated the dynamics of the real exchange rates in the region of East Asia, including Japan, Malaysia, Korea, Singapore, Philippines, Indonesia, and Thailand. The results through the method of generalized variance decompositions proved that essentials such as productivity differential elucidate a little and cannot be blamed for all the variations of the real exchange. In addition, Lee et al. (2002) found some real variables, namely trade and its terms along with industry output to have long-run significant impacts on real exchange rate. However, the nominal variables, are found to be insignificantly associated with the exchange rate in the selection regions. Other studies indicate the fact that exchange rate movements and volatility may have some meaningful contribution in overall regional output (Cheung \& Chinn, 2001; Gabaix \& Maggiori, 2015; Ghosh et al., 2016; Ilzetzki et al., 2017; Yip et al., 2017).

Numerous studies have considered the effect of market risk through interest rate in the economy. The interest rate determination is the interaction of demand and supply of the money in the financial market. Meanwhile, the findings of Fisher (1930), indicate that nominal interest is the sum of real interest rate and the expected rate of inflation in the economy over time.

However, it also suggests in present body of literature that there was a relationship between the interest rate (nominal) and the expected rate of inflation (Mishkin, 1992). To understand this idea, assuming 
identical financial assets in the stock market under two different states can reveal the idea of interest parity which specifies that the difference between the interest rate of two different economies is equal to the difference of exchange rate of two economies (Aliber, 1973; Dooley \& Isard, 1980; Juselius, 1995). This idea indicates the link between interest rate and exchange rate over time. Such findings also imply that the domestic rate of interest is equal to the interest rate in the foreign market with the expected exchange rate change (Dornbusch, 1976; Meese \& Rogofp, 1988). In addition, the assumption of loanable theory indicates that interest rate has a significant association with the demand and supply for loanable funds in the overall money market. The EK model has also been used by authors like Jankee (2003) to indicate the interest rate movement along with regional and financial market indicators. The study quotes empirical evidence for lower connections with financial markets at external context and the significance of internal aspects in local interest rate determination. However, it is found that both the interest rate parity and fisher effect are not found in the region. Another contribution by Ahmad and Ariff (2007) engages a modified form of the EK model to observe liberalization in financial terms and interest rate indicators in the region of Malaysia. The findings of the study indicate that fact that there exists a significant association between interest rate and a set of factors in Malaysia.

After the detailed analysis of present literature, a gap is found from the context of Kuwait that no study is yet to be presented, covering the exchange rate movement along with lagged predictors, market risk and financial sector indicators. Therefore, the present study tries to fill this gap as significant opportunity to conduct the empirical evidence during the time of 1980 to 2005 when the financial instability and exchange rate volatility was targeted the economy of Kuwait due to various internal and external factors.

\section{Descriptions of the Variables}

The factor of exchange rate is explained as the price of the one currency which can be measured in terms of another currency. To consider the exchange rate, two components are under consideration; the domestic currency and foreign currency. In existing literature, two major quotation methods are explained for the exchange rates and its determination (Fox \& Madura, 2017). The first one is known as the direct quotation while $2^{\text {nd }}$ is entitled as an indirect quotation. In a direct quotation, the price of units of a foreign currency is explained or defined regarding the units of domestic currency over a time. While in an indirect quotation, the price units of the domestic currency are expressed through units of foreign currency (Fox \& Madura, 2017). The quotes of exchange rate in the world economy are presented through US dollar, however, in the present financial markets, it can be quoted against any another domestic or national currency under the title of cross rate or cross currency (Chidoko, 2014; Purnama, 2014; Chidoko \& Mashavira, 2014; Santhi \& Gurunathan, 2014; Aura, et al., 2015; Eiteman et al., 2016; Okoli, 2017; Chima \& Kasim, 2018; Azad, et al., 2018). Numerous studies have considered the factor of the exchange rate to express the level of country risk and its exposure in the present literature. Besides, the lagged values of exchange rates are examined in the literature to predict its present status. Various studies have taken the lagged for the exchange rate as the key determinants of ER risk (Ajayi \& Mougouė, 1996; Basher et al., 2016; Eichenbaum et al., 2017; Feenstra, 1989; Ferraro et al., 2015; Somanath, 1986).

The concept of interest rate can be viewed as the cost incurred by the financial market on the borrowing of the money or the compensation paid for the lending of money from the borrowers. In addition, it is also expressed as the source of policy making for the monetary policy in an economy during specific time. For the allocation of the resource, the significance of interest rate and its implication in capital accumulation has been observed by the researchers in the field of finance (Benigno \& Woodford, 2003; Ford \& Laxton, 1999; Hoffmann et al., 2018; Kim \& Orphanides, 2012; Woodford, 2003; Albasu \& Nyameh, 2017).To explain a reasonable interest rate various experts have focused on the relationship between investment and savings factors while using the loanable funds into consideration (Keynes, 1936; Wicksell et al., 1936). Interest rate is determined by the interaction between the money supply

and demand for the supply; the liquidity preference approach. The factor of interest can also be viewed 
to express the level of market risk (English et al., 2018; Heider et al., 2015). The present study considers both the real interest rate and deposit interest rate.

From the financial sector, the factors like price level at the government and domestic credit facility to private sector are also added in the proposed models. The price level of the Government (PLG) is mainly used to express the consumption of education, part of the health care and other economic and financial policies. While the factor of domestic credit to private sectors (DCPS) mainly by the banking firms in the country consists of financial resources provided to the private sector and other depository corporations except the central bank in the economy through loans, purchase of financial assets, trade credits and other accounts receivables. Such loans normally cover the claims for the repayments. Both the factors of PLG and DCPS have not been very well addressed in the existing literature to explain the level of country risk and its exposure during a period. Therefore, the present research considers them among the predictors of country risk in Kuwait.

\section{Econometric Models}

To understand the in-depth impact of lagged predictors, market risk and financial sector indicators on $\mathrm{ER}$, the following regression equations are developed.

$y($ country risk: exchange rate volaility $)=\partial+\beta 1 \sim 1981,2005($ lagged $E R 1)+$

$\beta 2 \sim 1982,2005($ lagged ER2) $+\beta 3 \sim 1980,2005(D I R)+\beta 4 \sim 1980,2005(R I R)+\epsilon$,

where the first regression equation given in Eq. (1) measures the impact of lagged predictors of ER along with market risk factors on country risk. For the lagged 1, time is assumed from 1981 to 2005 which predicts the present value of country risk based on the one year lagged difference past values. For the $2^{\text {nd }}$ lag, time is from 1982 to 2005 considering the dependency of two years lagged on country risk. For market risk, both factors of deposit interest (DIR), and real interest rate (RIR) are under consideration. For Eq. (2), the impact of lagged values along with market risk and financial sector indicators of DCPS and PLG are considered as follows,

$$
\begin{aligned}
& y(\text { country risk: } \text { exchange rate volaility })=\partial+1 \sim 1981,2005(\text { lagged } E R 1)+ \\
& \beta 2 \sim 1982,2005(\text { lagged } E R 2)+\beta 3 \sim 1980,2005(D I R)+\beta 4 \sim 1980,2005(R I R)+ \\
& \beta 5 \sim 1980,2005(D C P S)+\beta 6 \sim 1980,2005(P L G)+\varepsilon .
\end{aligned}
$$

After the consideration of overall time series, $3^{\text {rd }}$ equation has observed the impact of lagged predictors, market isk along with financial sector indicator during the time of $1980 \mathrm{~s}$ to $1990 \mathrm{~s}$.

$$
\begin{aligned}
& y(\text { country risk: } \text { exchange rate volaility })=\partial+1 \sim 1981,1990(\text { lagged } E R 1)+ \\
& \beta 2 \sim 1982,1990(\text { lagged } E R 2)+\beta 3 \sim 1980,1990(D I R)+\beta 4 \sim 1980,1990(R I R)+ \\
& \beta 5 \sim 1980,1990(D C P S)+\beta 6 \sim 1980,1990(P L G)+\varepsilon
\end{aligned}
$$

Fourth regression equation has taken the time effect from 1991 to 2000 with all set of predictors and lagged estimators.

$y($ country risk: exchange rate volaility $)=\partial+1 \sim 1991,2000($ lagged ER 1$)+$ $\beta 2 \sim 1992,2000($ lagged ER2) $+\beta 3 \sim 1991,2000(D I R)+\beta 4 \sim 1991,2000(R I R)+$ $\beta 5 \sim 1991,2000(D C P S)+\beta 6 \sim 1991,2000(P L G)+\varepsilon$.

Fifth econometric model has taken the time of mid of 1990s and first half of the last decade; 2005.

$y($ country risk: exchange rate volaility $)=\partial+1 \sim 1995,2005($ lagged ER 1$)+$ $\beta 2 \sim 1996,2000($ lagged ER2) $+\beta 3 \sim 1995,2005(D I R)+\beta 4 \sim 1995,2005(R I R)+$ $\beta 5 \sim 1995,2005(D C P S)+\beta 6 \sim 1995,2005(P L G)+\varepsilon$. 
The last regression equation has covered the time span of fifteen years; 1991 to 2005 .

$y($ country risk: exchange rate volaility $)=\partial+1 \sim 1991,2005($ lagged ER 1$)+$ $\beta 2 \sim 1992,2005($ lagged ER2) $+\beta 3 \sim 1991,2005(D I R)+\beta 4 \sim 1991,2005(R I R)+$

$$
\beta 5 \sim 1991,2005(D C P S)+\beta 6 \sim 1991,2005(P L G)+\varepsilon \text {. }
$$

To measure the impact of stated indicators, detailed time series analysis both in aggregated and desegregated analysis have been performed. The reason to perform such analysis is to empirically estimate how the country risk in the region of Kuwait is being impact over the 26 years from the set of predictors with and without the presence of financial sector regression model. As provided in above equations, Eqs. (1-2) cover the whole-time while Eqs. (3-6) adopt the method of various time slots to provide the empirically contribution through disaggregated analysis.

\section{Discussion of Results}

\subsection{Descriptive results}

Table 1 indicates the data trends from 1980s to 2005 and the total number of observation for the stated data is equal to 26 , indicating an overall annual value. To collect the data, various sources like world development indicators, and Penn world table have been considered. Mean score for the country risk which is measured through exchange rate is 0.2934 and it indicates that an overall Kuwaiti dinar to US dollars is found to be in a stable position. Deviation in the mean score of exchange rate (ER) is found to very minor with the value of .009. Minimum ER from KWD to US is 0.27 while the maximum trend is .31 during 26 years of the study. To understand the impact of lagged predictors or past value of ER on its current value, lagged values have been calculated through L1 and L2 operators in STATA-14. For L1, the mean score is almost the same as the current values of ER; 0.2936 with the deviation from the mean is .0099 with similar range of observations. The mean score for the second lagged through L2 is equal to 0.29375 with the deviation of 0.01035 and symmetrical range. In addition, the impact of financial indicators for the country risk analysis under consideration through domestic credit to private sector (DCPS), price level of Government (PLG), deposit interest rate (DIR), and finally real interest rate (RIR) are under investigation. The mean score of DCPS is 54.90 with the deviation of 21.75 . While minimum level of DCPS is 17.16 and maximum of 93.54, respectively. The score of DCPS is measured as a $\%$ of GDP for 26 years. For the PLG the mean score of 106.96, deviation of 23.90 with the range from 60.13 to 111.53 respectively. In addition, the price level for the investment has a mean value of 91.79 and standard deviation of 9.45, respectively. Among the significant contributor for the ER, impact of interest rate through real and deposit proxies is also added in the model. An overall average trend of DIR is 5.92 with the standard deviation of 1.77 and range of 2.41 and 9.21 . For the real interest rate, the impact of RIR has a mean score of 6.54 and deviation of 14.52 with the maximum amount of 9.21 .

Table 1

Descriptive Results

\begin{tabular}{lccccc}
\hline Variable & Obs & Mean & Std. Dev. & Min & Max \\
\hline ER & 26 & 0.293462 & 0.009774 & 0.27 & 0.31 \\
DCPS & 26 & 54.90738 & 21.75985 & 17.1625 & 93.54561 \\
PLG & 26 & 106.9681 & 23.90353 & 62.58 & 213.65 \\
DIR & 26 & 5.929063 & 1.770295 & 2.417533 & 9.213333 \\
RIR & 26 & 6.543645 & 14.52825 & -25.0877 & 46.20142 \\
ERL1 & 25 & 0.2936 & 0.00995 & 0.27 & 0.31 \\
ERL2 & 24 & 0.29375 & 0.010135 & 0.27 & 0.31 \\
\hline
\end{tabular}

To explore the problem of autocorrelation which indicates the association between the key variables and error terms, corrgram technique is applied while taking the 12 lagged values of ER. 
Table 2 indicates the output for the corrgram. The value of AC indicates the correlation between the present value and its values over 3 years ago is .1605 , while for the $6^{\text {th }}$ year, this association is .0794 , for the $9^{\text {th }}$ year is -.0886 and for $12^{\text {th }}$ year, this relationship is found to be -.2003 as well. In addition, the value of PAC explains the correlation between the current value of ER along with the value of ER three years ago, which is .187 , for the $6^{\text {th }}$ year this value is -0.011 , for the $9^{\text {th }}$ year, is -.1508 and for the $11^{\text {th }}$ year is -.3546 .

Table 2

Corrgram ER, lags (12)

\begin{tabular}{cccc}
\hline LAG & AC & PAC & Q \\
\hline 1 & 0.6311 & 0.633 & 11.596 \\
2 & 0.2766 & -0.2677 & 13.917 \\
4 & 0.1605 & 0.187 & 14.732 \\
5 & 0.0443 & -0.1875 & 14.797 \\
6 & 0.0409 & 0.1675 & 14.855 \\
7 & 0.0794 & -0.011 & 15.085 \\
8 & 0.1307 & 0.4114 & 15.74 \\
9 & 0.0839 & -0.218 & 16.024 \\
10 & -0.0886 & -0.1508 & 16.361 \\
11 & -0.0792 & 0.3784 & 16.646 \\
12 & -0.0278 & -0.3546 & 16.683 \\
\end{tabular}

The value of Box-Pierce Q tests indicates the findings based on the null hypothesis that correlation, as explained earlier, is up to the lagged $k$, and equals to zero. Fig. 2 indicates the trend of cross-correlogram.

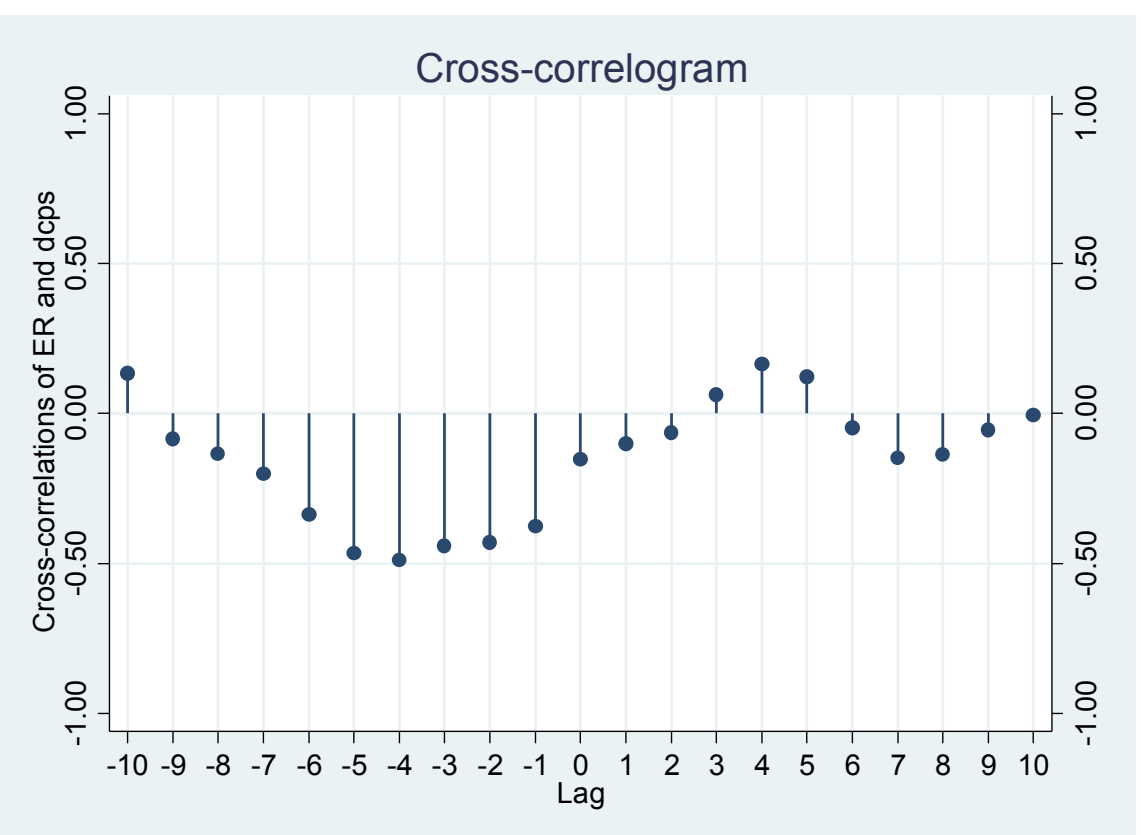

Fig. 2. Cross correlation between the ER and DCPS

To examine the cross-correlation between the two-time series, a method of xcorr is available in STATA which indicates the output through graph and cross-correlation with the help of Table 3. To explain the cross-correlation, DCPS and ER are under consideration with the findings given in Table 3 . The results indicate that at lagged zero, there is an immediate level of cross-correlation between the DCPS and ER which is equal to -.1526, indicating the fact that immediate decline in the value of DCPS causes a sudden increase in the value of ER. 
Table 3

Cross-correlation between ER and DCPS, lags(10)

\begin{tabular}{cccc}
\hline LAG & CORR & LAG & CORR \\
\hline-10 & 0.1345 & 1 & -0.1006 \\
-9 & -0.0831 & 2 & -0.0641 \\
-8 & -0.1356 & 3 & 0.0626 \\
-7 & -0.2007 & 4 & 0.1654 \\
-6 & -0.3377 & 5 & 0.1238 \\
-5 & -0.4671 & 6 & -0.0469 \\
-4 & -0.4897 & 7 & -0.1493 \\
-3 & -0.4402 & 8 & -0.1368 \\
-2 & -0.4293 & 9 & -0.054 \\
-1 & -0.3753 & 10 & -0.0052 \\
0 & -0.1526 & & \\
\hline
\end{tabular}

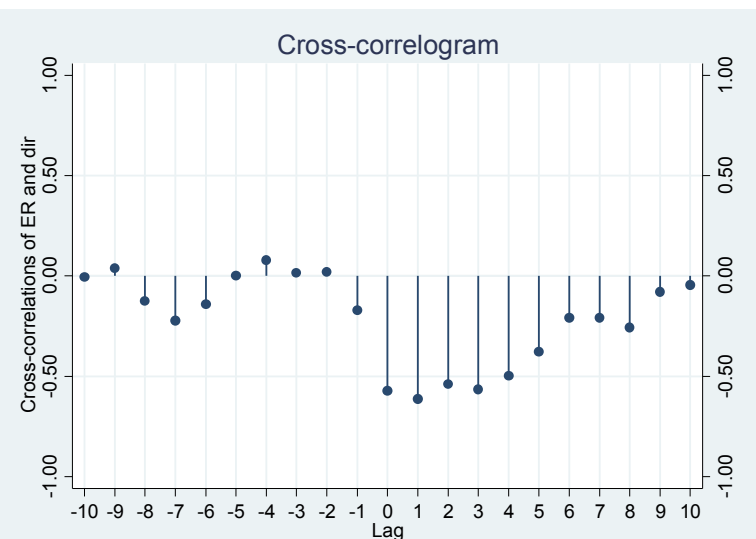

Fig. 3. Cross-correlation between the ER and DIR

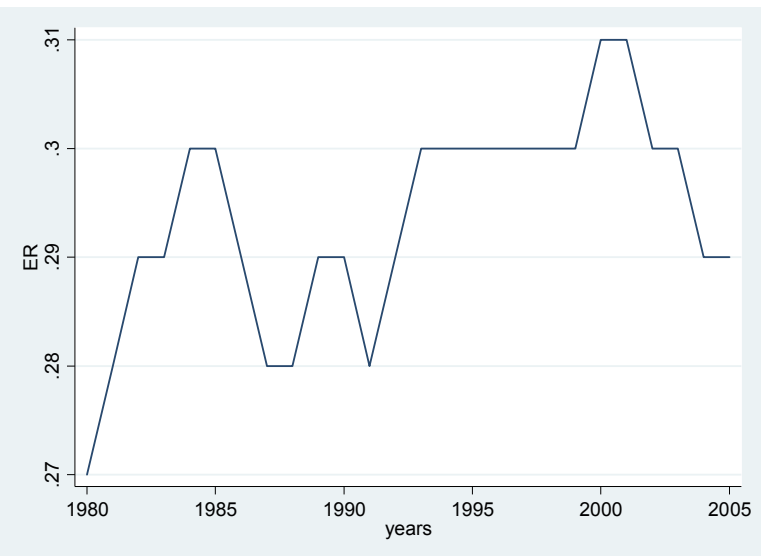

Fig. 4. Exchange Rate Volatility 1980-2005

Source: Author's Calculations, based on data from WDI and Penn-Word Table

Fig. 4 explains the trend of country risk in the form of exchange rate volatility from 1980 s to 2005 . It is found that during 1980-85, there is an up-word trend in the value of exchange rate defining a significant level of volatility. The reason behind this volatility is because of the presence of political instability and situation of war in the economy with lower economic growth in this time.

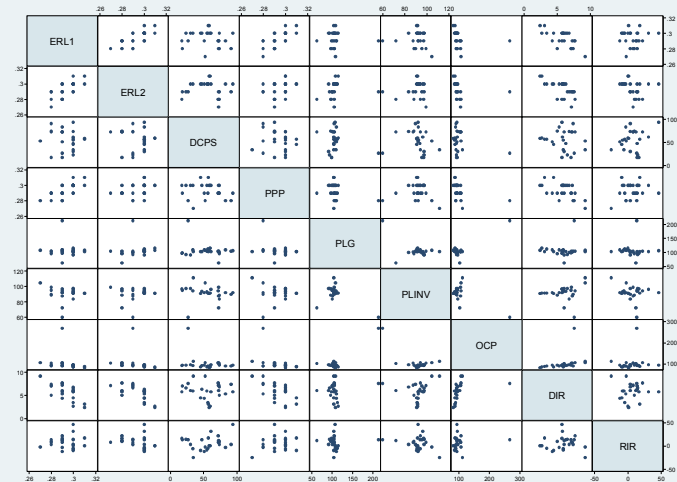

Fig. 5. Correlation between the Variables $1980-2005$

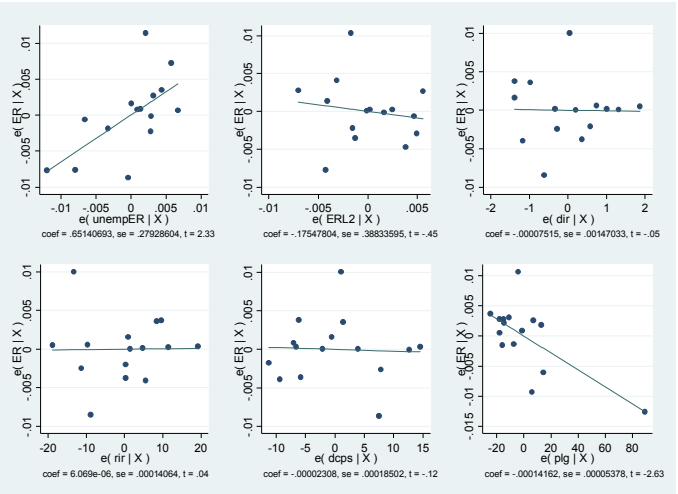

Fig. 6. AV plot of the Variables: 1980-2005

Source: Author's Calculations, based on data from WDI and Penn-Word Table

From 1985 to 1988 there is a sudden decline in the value of exchange rate which indicates a reasonable trend in the country. From 1990s to 2000, the trend in exchange rate is found to be increasing and 
touches the highest level of .31 as shown in Fig. 2. However, the trend of exchange rate volatility is in its decline phase from 2000 to 2005 . To predict the overall level of correlation among all the regression models of the study, during the whole-time period; 1980-2005. (See Fig. 6.)

\subsection{Empirical Findings}

After the detailed analysis of the time series trend of key variables, empirical results are presented in Table 4. For the overall time, impact of lagged ER and market risk factors on current values of the ER has been examined. The value of coefficient for the first lagged of ER known as ERL1 is .890 approximately with standard deviation of .1980 and t-statistics of 4.49. To accept the significant impact of past lagged values on present values of ER, the value of t-statistics should be greater than 1.96. The value of 4.49 explains the idea that there exists a significant impact of lagged values on the present values of ER. The coefficient of .890 explains a positive impact on ER and states that increasing lagged value of ER, putting an upward shift in the present trend of ER from 1980s to 2005. In addition, through

$2^{\text {nd }}$ lagged values of ERL2 is -.3591 which indicates that two years lagged values are negatively and significantly affecting the current values of ER. This impact is negatively significant at 1 per cent level of significance as p-value is $<.01$. However, the impact of market risk in the form of deposit interest rate and lending interest rate is -.0046 and -.0088 indicating their significant influences on ER in the region of Kuwait. However, both indicators of the market risks have shown their insignificant impacts on overall trend of ER during the time of 26 years. Overall robust explained variation in ER has been found to be .537 approximately and states a moderate level of change in ER through both lagged operators and market risk indicators. The value of F-statistics is 7.70 , significant at $1 \%$ level, which indicates that all the coefficient under the regression equation for the whole-time series are significantly different from zero.

Table 4

Regression Results Equation 1(1980-2005)

\begin{tabular}{|c|c|c|c|c|c|c|}
\hline ER & Coef. & Std. Err. & $\mathrm{T}$ & $P>t$ & [95\% Conf. & Interval] \\
\hline ERL1 & 0.8900309 & 0.1980947 & 4.49 & $0.000 * * *$ & 0.475414 & 1.304648 \\
\hline ERL2 & -0.7599191 & 0.18433 & -4.22 & $0.000 * * *$ & -0.74573 & 0.025888 \\
\hline DIR & -0.004673 & 0.010316 & -0.45 & 0.656 & -0.00263 & 0.001692 \\
\hline RIR & -0.00881 & 0.0091 & -0.96 & 0.345 & -0.00028 & 0.000102 \\
\hline cons & 0.1419048 & 0.0393172 & 3.61 & 0.002 & 0.059613 & 0.224197 \\
\hline
\end{tabular}

Under the title of $2^{\text {nd }}$ regression equation, the impact of lagged values of ER along market risk and financial sector indicators have been analyzed for ER. The impact of ERL1 is .740314 indicates that unit change in the value of lagged values of ER, causing a positive impact in the ER, in the presence of financial sector indicators. T-statistics for the first regression model is 5.47 with the p-value of .000 indicates the fact that the significant impact of L1 for ER is recorded in overall time series analysis. However, under the presence of financial sector indicators, the impact of ERL2 is -.2065, predicting an insignificant impact, hence adverse under the presence of financial sector indicators. The impact for both the market risk factors; DIR \& RIR is also insignificant and negative on ER. For the DCPS the coefficient of -.00011 explains that whenever more domestic credit will be given by the Kuwaiti Government, the value of currency will be declined. This impact is significant as t-statistics is 3.012. For PLG, similar negative impact of -.00011 is found with the p-value of .003. As per overall findings under regression Eq. (2), it is inference that lagged 1 for the ER are positively affecting the ER along with the DCPS and PLG. However, market risk factors are found to be insignificant predictors under model 2. Overall prediction in ER through set of explanatory variables is 68.88 percent, representing a good variation (See Table 5). The value of F-statistics is 10.49 found to be significant at $1 \%$, hence the no empirical objection for the goodness of fit. 
Table 5

Regression Results associated with Eq. (2) (1981-1990)

\begin{tabular}{lllllll}
\hline ER & Coef. & Std. Err. & $\mathrm{T}$ & $\mathrm{P}>\mathrm{t}$ & [95\% Conf. & Interval] \\
\hline ERL1 & 0.740314 & 0.1353414 & 5.47 & $0.000^{* * *}$ & 0.454769 & 1.025859 \\
ERL2 & -0.2065918 & 0.1482162 & -1.39 & 0.181 & -0.5193 & 0.106117 \\
DIR & -0.000241 & 0.0009511 & -0.25 & 0.803 & -0.00225 & 0.001766 \\
RIR & -0.0000409 & 0.0000745 & -0.55 & 0.59 & -0.0002 & 0.000116 \\
DCPS & -0.0001119 & 0.0000373 & -3.012 & $0.008 * * *$ & -0.00019 & $-3.3 \mathrm{E}-05$ \\
PLG & -0.0001189 & 0.0000351 & -3.39 & $0.003 * * *$ & -0.00019 & $-4.5 \mathrm{E}-05$ \\
CONS & 0.1582849 & 0.0378327 & 4.18 & $0.001 * * *$ & 0.078465 & 0.238105 \\
\hline
\end{tabular}

$\mathrm{F}(6,17)=10.49^{* * *} \quad$ Prob $>\mathrm{F}=.0001 \quad$ R-squared $=0.6888$

After the aggregated analysis, the sample period is divided into individual decades to check the impact of all the explanatory variables on the country risk factor. For the stated indicators the impact of the first lagged of ER has provided a significant evidence for the positive impact on ER from 1980 to 1990s (See Table 6). This empirical outcome is symmetrical to overall time series as explained in Table 2 and Table 3. The value of coefficient for RIR is .125 indicates a positive and significant impact on ER during the first decade of study. The rest of the indicators under the regression equation $3^{\text {rd }}$ are found to be insignificant including market risk and financial sector indicators. The value of F-statistics is 4.71 significant at $1 \%$ level, favour the research hypothesis that regression coefficients are significantly different from zero.

Table 6

Regression Results for Eq. (3) $(1980,1990)$

\begin{tabular}{lcccccc}
\hline ER & Coef. & Std. Err. & $\mathrm{t}$ & $\mathrm{P}>\mathrm{t}$ & {$[95 \%$ Conf. } & Interval] \\
\hline ERL1 & 0.324798 & 0.0773562 & 4.74 & $0.000^{* * *}$ & -2.98357 & 3.673165 \\
ERL2 & 0.117982 & 0.807843 & 0.15 & 0.897 & -3.35789 & 3.593851 \\
DIR & 0.001196 & 0.003444 & 0.35 & 0.761 & -0.01362 & 0.016014 \\
RIR & 0.125852 & 0.0315 & 3.96 & $0.000^{* * *}$ & -0.00123 & 0.001481 \\
DCPS & -0.00067 & 0.000715 & -0.94 & 0.446 & -0.00375 & 0.002405 \\
PLG & $2.96 E-05$ & 0.000243 & 0.12 & 0.914 & -0.00101 & 0.001074 \\
CONS & 0.196925 & 0.123575 & 1.59 & 0.252 & -0.33478 & 0.728626 \\
\hline
\end{tabular}

$\overline{\mathrm{F}}(6,2)=4.71^{* *} \quad$ Prob $>\mathrm{F}=0.009$

Fourth econometric model is developed to analyze the effect of set of explanatory variables for the country risk; ER. Time is from 1990 to 2000 with the annual observations of all the variables of the study (See Table 7). The first uneven findings during this time has insignificant impact of $2^{\text {nd }}$ lagged of country risk on ER. The value of coefficient for the first lagged ER is .29 indicating a significant impact on ER. It means that during the $2^{\text {nd }}$ decade of this study, the present value of country risk was depending on the past values of ER.

Table 7

Regression Results Eq. (4) (1991-2000)

\begin{tabular}{lcccccc}
\hline ER & Coef. & Std. Err. & $\mathrm{t}$ & $\mathrm{P}>\mathrm{t}$ & {$[95 \%$ Conf. } & Interval] \\
\hline ERL1 & 0.298367 & 0.128357 & 2.32 & $0.0103^{* *}$ & -0.11012 & 0.706857 \\
ERL2 & -0.0447 & 0.182465 & -0.24 & 0.822 & -0.62539 & 0.535984 \\
DIR & -0.00545 & 0.001265 & -4.31 & $0.023^{* *}$ & -0.00947 & -0.00142 \\
RIR & $-1.7 \mathrm{E}-05$ & $6.59 \mathrm{E}-05$ & -0.26 & 0.813 & -0.00023 & 0.000193 \\
DCPS & $-2 \mathrm{E}-05$ & $8.27 \mathrm{E}-05$ & -0.24 & 0.823 & -0.00028 & 0.000243 \\
PLG & $-8.4 \mathrm{E}-05$ & $2.23 \mathrm{E}-05$ & -3.78 & $0.032^{* *}$ & -0.00016 & $-1.3 \mathrm{E}-05$ \\
$\mathrm{CONS}$ & 0.266595 & 0.051992 & 5.13 & 0.014 & 0.101133 & 0.432057 \\
\hline $\mathrm{F}(6,3)$ & $29.70 \quad$ Prob $>\mathrm{F}$ & $=0.0091$ & R-squared $=$ & 0.9834 & Adj R-squared $=0.9503$ &
\end{tabular}

The impact of DIR is also found to be negatively significant with the coefficient of -.00545 significant at $5 \%$ level. The change in the value of PLG states a negative impact of 8.4E-.05 in country risk as tvalue is 3.78; above the threshold point of 1.96. F-statistic also provides the evidence for the fitness of 
the model 3 with the value of 29.70 , which is significant at $1 \%$. The significant contribution of present model has explained variation in country risk; 91.34 with the adjusted value of 85.03 respectively.

Under the $5^{\text {th }}$ regression model, the effect of explanatory variables along market risk and financial sector indicators are analyzed for the ER during 1995 to 2005 (Table 8). The main contribution of this time period is that none of the regression coefficients for the stated factors is found to be significant including the lagged values of ER. As the regression coefficients do not provide any satisfactory evidence for the significant variation in ER, the value of F-statistics is found to be lower than he threshold point of 3.50 .

Table 8

Regression Results Equation 5 (1995, 2005)

\begin{tabular}{lcccccc}
\hline ER & Coef. & Std. Err. & $\mathrm{T}$ & $\mathrm{P}>\mathrm{t}$ & {$[95 \%$ Conf. } & Interval] \\
\hline ERL1 & 0.743621 & 0.620202 & 1.2 & 0.297 & -0.97834 & 2.465578 \\
ERL2 & -0.16516 & 0.820106 & -0.2 & 0.85 & -2.44214 & 2.111819 \\
DIR & 0.000157 & 0.003007 & 0.05 & 0.961 & -0.00819 & 0.008504 \\
RIR & $-6.84 \mathrm{E}-06$ & 0.000262 & -0.03 & 0.98 & -0.00074 & 0.000721 \\
DCPS & $-3.3 \mathrm{E}-05$ & 0.000391 & -0.08 & 0.937 & -0.00112 & 0.001054 \\
PLG & -0.0002 & 0.000583 & -0.34 & 0.75 & -0.00182 & 0.001421 \\
CONS & 0.148194 & 0.3031 & 0.49 & 0.65 & -0.69335 & 0.989735 \\
\hline F $(6,4)$ & $0.54 \quad$ Prob $>\mathrm{F}$ & $=0191$ & & & &
\end{tabular}

The last regression model considers the lagged factors, market risk and two indicators from the financial sector under the title of DCPS and PLG from 1991 to 2005 (Table 9).

Table 9

Regression Results Eq. (6) (1991-2005)

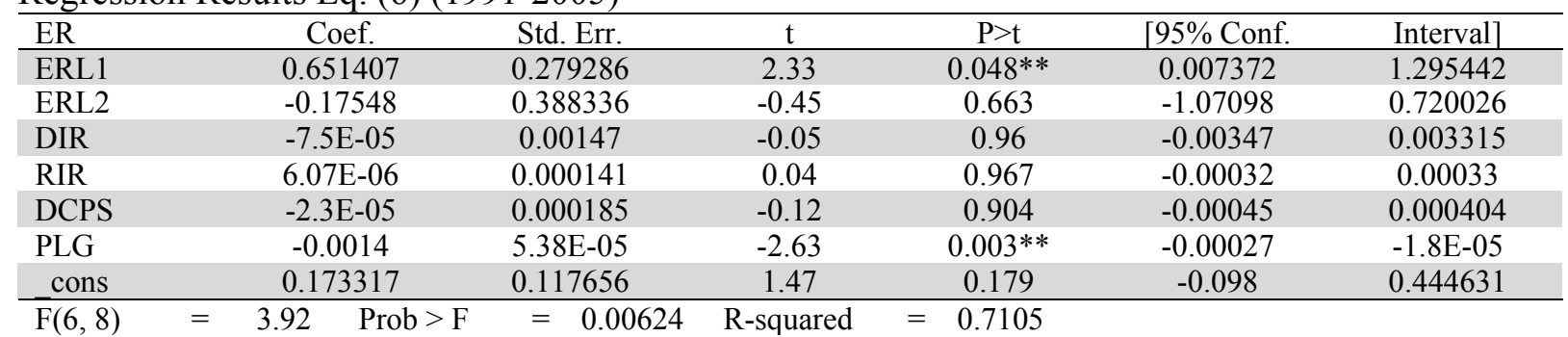

It is found that during this time, the impact of previous values of ER on present values is significantly positive, which indicates that an increase in the level of the past ER volatility may cause an increase in volatility at present. In addition, from the financial sector, the impact of PLG is significantly negative. Overall fitness of the model has just cross the threshold point of 3.50 with the good value of R-square of the model.

\section{Conclusion and Future Implications}

From the context of exchange rate risk in the field of corporate and international finance, earlier studies have empirically examined the association between the exchange rate fluctuations and various trade factors in the world economy. However, the findings of existing studies remained inappropriate because of little attention to the combined effect of lagged ER, market risk and financial sector indicators on country risk. In addition, research studies have been conducted in an aggregated method, however, no significant time series study was presented from the context of Kuwait while taking both aggregated and disaggregated analysis of exchange rate risk exposure. Therefore, the author have examined this gap and provided a meaningful contribution while applying econometric regression analysis for both overall time series and based on stated ranges. From the context of lagged predictors, first and second lagged have been calculated which measured the effect of past values of ER present values. For the market, two indicators; deposit interest rate and real interest have been added to the models. While from the financial sector, predictors DCPS and PLG were added for the empirical findings. It has been 
expressed that for the overall time of 26 years, the effect of both lagged predictors on ER was found to be significant with the presence of market risk factors. However, with the addition of financial sector indicators, the effect of the first lagged along with financial sector factors were significantly described the exchange rate risk. For the first subsample of 1980-1990, lagged operator 1 and real interest rate have maintained significant impacts on exchange rate volatility. For the time period 1991-2000, lagged 1, DIR and PLG presented a significant influence for ER risk in the region of Kuwait. While for the time of 1995-2005, none of the explanatory variables has shown any significant impact on ER. However, for the sample period of 1991-2005, lagged ER1 and PLG significantly affected the ER.

As per stated findings, it is suggested that past events related to volatility in ER are significantly affecting the value of country risk which needs serious attention. In addition, the present findings also suggest that policymakers may have to put more concerned with the exchange rate risk while considering the economic and financial improvement in Kuwait for a longer time. The present study also collaborates the argument that market risk is a factor for the stability in exchange rate which can lead to less vulnerability in ER. However, the following limitations should be addressed in upcoming tenure.

- This study has used the time of 1980 s to 2005 and due to missing observations, latest time is missing. However, future work can be continued for the up to mark date by considering the exchange rate and market risk exposure along with financial sector indicators.

- This study has taken just a region of Kuwait for the overall analysis while ignoring the neighbouring regions. Future studies can be conducted in cross-sectional pattern with the addition of some other factors like foreign investment, financial market stability with the lagged effect of ER exposure.

\section{References}

Aftab, M., \& Rehman, I. U. (2017). Exchange rate risk and the bilateral trade between Malaysia and Singapore. Studies in Economics and Finance, 34(3), 407-426.

Ahmad, N. H., \& Ariff, M. (2007). Multi-country study of bank credit risk determinants. International Journal of Banking and Finance, 5(1), 6.

Ajayi, R. A., \& Mougoue, M. (1996). On the dynamic relation between stock prices and exchange rates. Journal of Financial Research, 19(2), 193-207.

Albasu, J., \& Nyameh, J. (2017). Relevance of stakeholders theory, organizational identity theory and social exchange theory to corporate social responsibility and employees performance in the commercial banks in Nigeria. International Journal of Business, Economics and Management, 4(5), 95-105.

Aliber, R. Z. (1973). The interest rate parity theorem: A reinterpretation. Journal of political economy, 81(6), 1451-1459.

Arize, A. C., Osang, T., \& Slottje, D. J. (2000). Exchange-rate volatility and foreign trade: evidence from thirteen LDC's. Journal of Business \& Economic Statistics, 18(1), 10-17.

Aura, C. M., Hassan, F., Osore, M. K., Musa, S., Morara, G., \& Uku, J. (2015). A comprehensive public-private partnership concept for resources sustainability from a mega-project management multi-level perspective. International Journal of Management and Sustainability, 4(11), 218-236.

Azad, A. M. S., Raza, A., \& Zaidi, S. S. Z. (2018). Empirical relationship between operational efficiency and profitability (Evidence from Pakistan Exploration Sector). Journal of Accounting, Business and Finance Research, 2(1), 7-11.

Bahmani-Oskooee, M., \& Harvey, H. (2006). How sensitive are Malaysia's bilateral trade flows to depreciation? Applied Economics, 38(11), 1279-1286.

Balassa, B. (1964). The purchasing-power parity doctrine: a reappraisal. Journal of political economy, 72(6), 584-596.

Basher, S. A., Haug, A. A., \& Sadorsky, P. (2016). The impact of oil shocks on exchange rates: a Markovswitching approach. Energy Economics, 54, 11-23.

Benigno, P., \& Woodford, M. (2003). Optimal monetary and fiscal policy: A linear-quadratic approach. NBER Macroeconomics Annual, 18, 271-333.

Cheung, Y.-W., \& Chinn, M. D. (2001). Currency traders and exchange rate dynamics: a survey of the US market. Journal of International Money and Finance, 20(4), 439-471. 
Chidoko, C. (2014). Labor and Economic Growth in Zimbabwe. The Economics and Finance Letters, 1(4), 2429.

Chidoko, C., \& Mashavira, N. (2014). An analysis of corporate governance in the banking sector of Zimbabwe. Humanities and Social Sciences Letters, 2(3), 174-180.

Chima, P \& Kasim, U (2018). Public-private partnership as a strategy for e-governance funding in Africa: The gains and the pains. International Journal of Public Policy and Administration Research, 5(2), 37-47.

Doğanlar, M. (2002). Estimating the impact of exchange rate volatility on exports: evidence from Asian countries. Applied Economics Letters, 9(13), 859-863.

Dooley, M. P., \& Isard, P. (1980). Capital controls, political risk, and deviations from interest-rate parity. Journal of Political Economy, 88(2), 370-384.

Dornbusch, R. (1976). Expectations and exchange rate dynamics. Journal of Political Economy, 84(6), 11611176.

Doroodian, K. (1999). Does exchange rate volatility deter international trade in developing countries? Journal of Asian Economics, 10(3), 465-474.

Eichenbaum, M., Johannsen, B. K., \& Rebelo, S. (2017). Monetary policy and the predictability of nominal exchange rates: National Bureau of Economic Research.

Eiteman, D. K., Stonehill, A. I., \& Moffett, M. H. (2007). Multinational business finance.

Eiteman, D. K., Stonehill, A. I., \& Moffett, M. H. (2016). Multinational business finance. Pearson Higher Ed.

English, W. B., Van den Heuvel, S. J., \& Zakrajšek, E. (2018). Interest rate risk and bank equity valuations. Journal of Monetary Economics, 98, 80-97.

Fattouh, B. (2007). The drivers of oil prices: the usefulness and limitations of non-structural model, the demandsupply framework and informal approaches.

Feenstra, R. C. (1989). Symmetric pass-through of tariffs and exchange rates under imperfect competition: An empirical test. Journal of International Economics, 27(1-2), 25-45.

Ferraro, D., Rogoff, K., \& Rossi, B. (2015). Can oil prices forecast exchange rates? An empirical analysis of the relationship between commodity prices and exchange rates. Journal of International Money and Finance, 54, 116-141.

Ford, R., \& Laxton, D. (1999). World public debt and real interest rates. Oxford Review of Economic Policy, 15(2), 77-94.

Fox, R., \& Madura, J. (2017). International Financial Management. 4th ed., Cengage Learning.

Fx-exchnage. (2018). Kuwaiti Dinar(KWD) To US Dollar(USD) History. Retrieved 04-10-2018, 2018, from https://www.fx-exchange.com/kwd/usd-exchange-rates-history.html

Gabaix, X., \& Maggiori, M. (2015). International liquidity and exchange rate dynamics. The Quarterly Journal of Economics, 130(3), 1369-1420.

Ghosh, A. R., Ostry, J. D., \& Chamon, M. (2016). Two targets, two instruments: monetary and exchange rate policies in emerging market economies. Journal of International Money and Finance, 60, 172-196.

Ghura, D., \& Grennes, T. J. (1993). The real exchange rate and macroeconomic performance in Sub-Saharan Africa. Journal of Development Economics, 42(1), 155-174.

Hall, M. G. (2018). Exchange rate crises in developing countries: the political role of the banking sector. Routledge.

Heider, F., Hoerova, M., \& Holthausen, C. (2015). Liquidity hoarding and interbank market rates: The role of counterparty risk. Journal of Financial Economics, 118(2), 336-354.

Hoffmann, P., Klaus, B., \& Langfield, S. (2018). The distribution of interest rate risk in the euro area. Financial Stability Review.

Hooper, P., \& Kohlhagen, S. W. (1978). The effect of exchange rate uncertainty on the prices and volume of international trade. Journal of International Economics, 8(4), 483-511.

Ilzetzki, E., Reinhart, C. M., \& Rogoff, K. S. (2017). The Country Chronologies to Exchange Rate Arrangements into the 21st Century: will the anchor currency hold? (No. w23135). National Bureau of Economic Research.

Jankee, K. (2003). Interest rate determination in the post-liberalization period in Mauritius. Law, Management and Social Sciences Research Journal, 5, 1-18.

Juselius, K. (1995). Do purchasing power parity and uncovered interest rate parity hold in the long run? An example of likelihood inference in a multivariate time-series model. Journal of Econometrics, 69(1), 211240.

Keynes, J. M. (1936). The general theory of employment, investment, and money. London and New York, quoted from:

https://sites. google. com/site/biblioeconomicus/KeynesJohnMaynard-TheGeneralTheoryOf EmploymentInterestAndMoney. pdf [Accessed 07 Jan 2014]. 
Kim, D. H., \& Orphanides, A. (2012). Term structure estimation with survey data on interest rate forecasts. Journal of Financial and Quantitative Analysis, 47(1), 241-272.

Lee, M., Nziramasanga, M., \& Ahn, S. K. (2002). The real exchange rate: an alternative approach to the PPP puzzle. Journal of Policy Modeling, 24(6), 533-538.

Madura, J., \& McCarty, D. E. (1989). Research trends and gaps in international financial management: a note. Management International Review, 29(2), 75-79.

Madura, J., \& Zhang, J. (2006). International corporate finance. Thomson/South-Western.

Meese, R., \& Rogofp, K. (1988). Was it real? The exchange rate-interest differential relation over the modern floating-rate period. The Journal of Finance, 43(4), 933-948.

Mishkin, F. S. (1992). Is the Fisher effect for real?: A reexamination of the relationship between inflation and interest rates. Journal of Monetary Economics, 30(2), 195-215.

Miyakoshi, T. (2003). Real exchange rate determination: Empirical observations from East-Asian countries. Empirical Economics, 28(1), 173-180.

Nyen Wong, K., \& Cheong Tang, T. (2008). The effects of exchange rate variability on Malaysia's disaggregated electrical exports. Journal of Economic Studies, 35(2), 154-169.

Obstfeld, M., \& Rogoff, K. (1995). Exchange rate dynamics redux. Journal of Political Economy, 103(3), 624660.

Okoli, A. C. (2017). Disarmament, Demobilization and Reintegration (DDR) in Rwanda, 1997-2008: A Desk Exegesis and Agenda for Praxis. International Journal of Emerging Trends in Social Sciences, 1(1), 1-8.

Purnama, C. (2014). Improved performance through empowerment of small industry. Journal of Social Economics Research, 1(4), 72-86.

Santhi, N. S., \& Gurunathan, K. B. (2014). Fama-French three factors model in Indian mutual fund market. Asian Journal of Economics and Empirical Research, 1(1), 1-5.

Sauer, C., \& Bohara, A. K. (2001). Exchange rate volatility and exports: regional differences between developing and industrialized countries. Review of International Economics, 9(1), 133-152.

Sercu, P., \& Uppal, R. (2006). Exchange rate volatility, trade, and capital flows under alternative exchange rate regimes. Cambridge University Press.

Sercu, P., \& Vanhulle, C. (1992). Exchange rate volatility, international trade, and the value of exporting firms. Journal of Banking \& Finance, 16(1), 155-182.

Somanath, V. S. (1986). Efficient exchange rate forecasts: lagged models better than the random walk. Journal of International Money and Finance, 5(2), 195-220.

Su, S. (2018). An Investigation of Foreign Exchange Risk Management in Chinese Multinational Companies Compared with US and UK MNEs. Advances in Social Science, Education and Humanities Research, 176, 530-534.

Wicksell, K., Kahn, R. F., Ohlin, B., Uhr, C. G., \& Kahn, R. F. (1936). Interest and prices: a study of the causes regulating the value of money. Macmillan London.

Wong, K. N., \& Tang, T. C. (2011). Exchange rate variability and the export demand for Malaysia's semiconductors: an empirical study. Applied Economics, 43(6), 695-706.

Woodford, M. (2003). Optimal interest-rate smoothing. The Review of Economic Studies, 70(4), 861-886.

Yiadom, K. B. (2016). An investigation into the effects of foreign exchange rate risk on stock prices: evidence from Ghana Stock Exchange (Doctoral dissertation).

Yip, P. S., Tse, Y.-K., \& Dong, Y. (2017). The exchange rate system reform in China: US pressure, implicit gradual appreciation and explicit exchange rate bands. Nanyang Technological University, School of Social Sciences, Economic Growth Centre.

Lubis, M. A., \& Wekke, I. S. (2009). Integrated Islamic education in Brunei Darussalam: the hopes and challenges. EDUCARE, 1(2).

Suardi Wekke, I., Yandra, A., \& Hamuddin, B. (2017, December). Learning strategy in class management. $A$ Reflection from Manado Case. In IOP Conference Series: Earth and Environmental Science (Vol. 97, No. 1, p. 012053).

Wekke, I. S. (2015). Curriculum development in Madrasa: Exploration from Muslim minority of west Papua. Jurnal Pendidikan Islam, 1(3), 372-392.

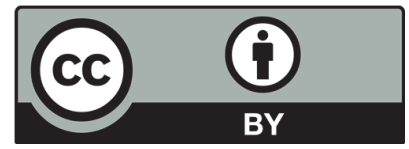

(C) 2019 by the authors; licensee Growing Science, Canada. This is an open access article distributed under the terms and conditions of the Creative Commons Attribution (CC-BY) license (http://creativecommons.org/licenses/by/4.0/). 